GRASAS Y ACEITES 65 (3)

July-September 2014, e037

ISSN-L: 0017-3495

doi: http://dx.doi.org/10.3989/gya.0234141

\title{
Effect of genotype on fatty acid composition of intramuscular and subcutaneous fat of Celta pig breed
}

\author{
R. Domínguez and J.M. Lorenzo \\ Centro Tecnológico de la Carne de Galicia, Rúa Galicia Nº 4, Parque \\ Tecnológico de Galicia, San Cibrán das Viñas, 32900 Ourense, Spain \\ Corresponding author: jmlorenzo@ceteca.net
}

Submitted: 21 February 2014; Accepted: 28 April 2014

\begin{abstract}
SUMMARY: A total of 45 Celta breed pigs were used to investigate the effect of genotype (Barcina, Carballiña and Santiaguesa lines) on the fatty acid composition of intramuscular (IMF) and subcutaneous fat (SF). The total IMF content was influenced by genotype ( $\mathrm{P}<0.05)$, since the Barcina line had the highest levels $(5.21 \%$ vs 1.99 and $3.59 \%$ for Santiaguesa and Carballiña lines, respectively). The total and neutral lipids from the IMF of the Santiaguesa line displayed higher contents of PUFA than the other two lines. The nutritional indices were also affected by genotype, since the Santiaguesa line presented the lowest atherogenic (AI) and thrombogenic (TI) indices and the highest hypocholesterolemic/hypercholesterolemic ratio $(\mathrm{h} / \mathrm{H})(\mathrm{P}<0.05)$. The IMF total and neutral lipids presented higher $(\mathrm{P}<0.05)$ values of MUFA than SF, while the PUFA content was greatest in $\mathrm{SF}(\mathrm{P}<0.05)$. Regarding the polar fraction, samples from IMF presented the highest values of PUFA (between 37-44\%). Finally, SF showed higher percentages of MUFA and SFA than IMF $(\mathrm{P}<0.05)$. The differences in IMF content and back fat thickness imply that the deposition of IMF and SF may be regulated by different mechanism among the three lines.
\end{abstract}

KEYWORDS: Celta pig breed; Fatty acid profile; Genotype; Location in the carcass

RESUMEN: Efecto del genotipo sobre la composición de ácidos grasos de la grasa intramuscular y subcutánea de cerdos de raza Celta. Un total de 45 cerdos de raza Celta fueron usados para estudiar el efecto del genotipo (líneas Barcina, Carballiña y Santiaguesa) sobre la composición de ácidos grasos de la grasa intramuscular y subcutánea. El contenido en grasa intramuscular estuvo influenciado por el genotipo $(\mathrm{P}<0.05)$; la Barcina presentó los mayores valores (5.21\% vs 1.99 y 3.59 para las líneas Santiaguesa y Carballiña respectivamente). Los lípidos totales y neutros de la grasa intramuscular de la línea Santiaguesa mostraron mayores contenidos de PUFA que las otras dos líneas. Los índices nutricionales también se vieron influenciados por el genotipo; la línea Santiguesa presentó los menores valores de los índices aterogénico y trombogénico y los mayores de la relación entre ácidos grasos hipo e hipercolesterolémicos. En los lípidos totales y neutros de la grasa intramuscular se obtuvieron mayores valores de MUFA y menores de PUFA $(\mathrm{P}<0.05)$ que en la grasa subcutánea. En los lípidos polares, las muestras de grasa intramuscular presentaron los mayores valores de PUFA (entre 37-44\%). Finalmente, la grasa subcutánea mostró valores superiores de MUFA y SFA que la intramuscular $(\mathrm{P}<0.05)$. Las diferencias en el contenido de grasa intramuscular y de espesor de grasa subcutánea implica que su deposición puede estar regulada por diferentes mecanismos.

PALABRAS CLAVE: Cerdo de raza Celta; Genotipo; Localización en la canal; Perfil de ácidos grasos

Citation/Cómo citar este artículo: Domínguez R, Lorenzo JM. 2014. Effect of genotype on fatty acid composition of intramuscular and subcutaneous fat of celta pig breed. Grasas Aceites $\mathbf{6 5}$ (3): e037. doi: http://dx.doi.org/10.3989/ gya.0234141.

Copyright: (C) 2014 CSIC. This is an open-access article distributed under the terms of the Creative Commons Attribution-Non Commercial (by-nc) Spain 3.0 Licence. 


\section{INTRODUCTION}

The Celta pig is an autochthonous breed reared in the north- west of the Iberian Peninsula. These pigs are reared under extensive production systems and fed with balanced diets and natural sources, being slaughtered at $>140 \mathrm{~kg}$ live weight.

The Celta pig breed has a high content of intramuscular fat (Franco and Lorenzo, 2013). Previous studies have shown that muscles from rustic pig breeds, in contrast to the muscle from selected pig breeds, contain higher amounts of intramuscular lipids (Morales et al., 2002; Cava et al., 2003). Moreover, the amount of intramuscular fat influences the fatty acid profiles of the lipid fractions. This may have important consequences on the oxidative stability of meat and meat products (Cava et al., 2004).

Previous studies have evaluated the influence of carcass location (Martínez et al., 2007; Lorenzo et al., 2012), sex (Lorenzo et al., 2012), crossbreed (Franco et al., 2014) and diet (Franco et al., 2006; Bermúdez et al., 2012) on the fatty acid profile in Celta pigs, but there are no studies about the differences in fatty acid compositions among Celta pig breed lines.

It is well known that within the Celta pig breed, three genotypes differ significantly (Santiaguesa, Barcina and Carballiña). The three lines are morphologically identical, and only differ in the absence or presence of pigmentation and in place of origin (Carril et al., 2012). Thus, the aim of this research was to study the influence of genotype on the fatty acid profile from different fat locations (intramuscular, subcutaneous dorsal and subcutaneous ventral) of the Celta pig breed.

\section{MATERIAL AND METHODS}

\subsection{Experimental design and animal management}

For this study, 45 castrated pigs (males and females) from the Celta breed (15 Barcina line, 15 Carballiña line and 15 Santiaguesa line) were used. All specimens, registered in the Record of Births of the Stud-Book were obtained from ASOPORCEL. All the animals were reared under the extensive system. The pigs were fed ad libitum with a commercial concentrate suited to the nutritive needs of the animals. Table 1 shows the chemical composition and fatty acid profile of the commercial feed. The animals were slaughtered at 16 months of age. The day before slaughter, the animals were weighed and transported to the abattoir trying to minimize stress. The pigs were slaughtered in an accredited abattoir (Lugo, Spain), using carbon dioxide to stun the animals.

After 45 min post-mortem, the dorsal fat thickness was measured with a flexible tape at the level
TABLE 1. Chemical composition and fatty acid profile of the commercial feed

\begin{tabular}{lr}
\hline Chemical composition (\%) & \\
Crude Protein & 15.3 \\
Ash & 5.5 \\
Fat & 3.5 \\
Celulose & 3.5 \\
Lysine & 0.7 \\
Methionine & 0.2 \\
Phosphate & 0.5 \\
Ca & 1.1 \\
Na & 0.1 \\
Fatty acid profile (\%) & \\
C16:0 & 15.56 \\
C16:1 & 0.12 \\
C18:0 & 2.63 \\
C18:1n9c & 25.24 \\
C18:2n6c & 48.89 \\
C20:0 & 0.42 \\
C18:3n3 & 6.23 \\
C22:0 & 0.45 \\
C20:5n3 & 0.11 \\
C24:1 & 0.19 \\
SFA & 19.15 \\
MUFA & 25.56 \\
PUFA & 55.28 \\
En-6/n-3 & 0.24 \\
\hline & 7.70 \\
\hline
\end{tabular}

The concentrate was formulated using the following ingredients (\%): 40 wheat, 25.5 barley, 15 soybean flour, 14.6 corn, 1.5 soybean oil, 2 calcium carbonate, 1 dicalcium phosphate and 0.20 sodium chloride.

of the first rib. Carcasses were chilled at $4{ }^{\circ} \mathrm{C}$ in a cold chamber for $24 \mathrm{~h}$ and cold carcass weight was recorded. The samples of fat, one per deposit, were taken from three different deposits (intramuscular from longissimus dorsi muscle, subcutaneous ventral and subcutaneous dorsal). The samples were transported to the laboratory under refrigeration $\left(<4{ }^{\circ} \mathrm{C}\right)$ and analyzed on the day of collection.

\subsection{Reagents}

Fatty acid methyl ester (FAMEs) standard mixtures and nonadecanoic acid were acquired from Supelco Inc. (Bellefonte, PA, USA). Analytical grade and liquid chromatographic grade chemicals were purchased from Merck Biosciences (Darmstadt, Germany). Boron trifluoride (14\% solution in methanol) was obtained from Panreac 
(Castellar del Vallès, Barcelona, Spain). $\mathrm{NH}_{2}-\mathrm{SPE}$ columns $(1 \mathrm{~mL} \times 100 \mathrm{mg})$ were acquired from Waters (Cerdanyola del Vallès, Spain).

\subsection{Analysis of fatty acid methyl esters}

IMF was extracted using chloroform/metanol $(2 / 1 ; \mathrm{v} / \mathrm{v})$ according to the method proposed by Folch et al. (1957) whereas the adipose fat was extracted following the procedure described by De Pedro et al. (1997) and stored at $-80^{\circ} \mathrm{C}$ until analysis by preparation of FAMEs.

Lipids were trans-esterified with a solution of boron trifluoride (14\%) in methanol (Carreau and Dubacq, 1978). For the total fatty acid analysis, $50 \mathrm{mg}$ of the extracted lipids were esterified while the neutral and polar fractions were separated using $\mathrm{NH}_{2}$-SPE columns according to the procedure developed by Kaluzny et al. (1985). FAMEs were stored at $-80{ }^{\circ} \mathrm{C}$ until chromatographic analysis. Separation and quantification of the FAMEs was carried out using a gas chromatograph (GC-Agilent 6890N; Agilent Technologies Spain, S.L., Madrid, Spain) equipped with a flame ionization detector and an automatic sample injector HP 7683, and using a Supelco SPTM-2560 fused silica capillary column ( $100 \mathrm{~m}, 0.25 \mathrm{~mm}$ i.d., $0.2 \mu \mathrm{m}$ film thickness). The chromatographic conditions were as follows: initial column temperature $120^{\circ} \mathrm{C}$, maintaining this temperature for $5 \mathrm{~min}$, programmed to increase at a rate of $5^{\circ} \mathrm{C} \cdot \mathrm{min}^{-1}$ up to $200^{\circ} \mathrm{C}$, maintaining this temperature for $2 \mathrm{~min}$, then at $1{ }^{\circ} \mathrm{C} \cdot \mathrm{min}^{-1}$ up to $230^{\circ} \mathrm{C}$, maintaining this temperature for $3 \mathrm{~min}$. The injector and detector were maintained at 260 and $280^{\circ} \mathrm{C}$, respectively. Helium was used as the carrier gas at a constant flow-rate of $1.1 \mathrm{~mL} \cdot \mathrm{min}^{-1}$, with the column head pressure set at $35.56 \mathrm{psi}$. The split ratio was 1:50 and $1 \mu \mathrm{L}$ of solution was injected. Nonadecanoic acid (C19:0) at $0.3 \mathrm{mg} \cdot \mathrm{mL}^{-1}$ was used as internal standard and added to the samples prior to fat extraction and methylation. Individual FAMEs were identified by comparing their retention times with those of authenticated standards (Supelco 37 component FAME Mix). Data regarding FAME composition were expressed in percentage according to the weight of the total identified FAMEs. The proportion of polyunsaturated (PUFA) (C18:2 n6; C18:3 n3; C20:2 $n 6$; and $\mathrm{C} 20: 4$ n6), monounsaturated (MUFA) (C16:1 $n 7$; C18:1 c-n9; and C20:1 n9) and saturated (SFA) (C14:0; C16:0; C18:0; and C20:0) fatty acid contents and PUFA/SFA ratio (P/S) were calculated. The atherogenic index (AI) and thrombogenic index (TI) were calculated according to Ulbricht and Sauthgate, (1991): AI $=[\mathrm{C} 12: 0+(4 * \mathrm{C} 14: 0)+\mathrm{C} 16: 0] /$ $[(\Sigma$ PUFA $)+(\Sigma$ MUFA $)]$

$\mathrm{TI}=[\mathrm{C} 14: 0+\mathrm{C} 16: 0+\mathrm{C} 18: 0] /\left[\left(0.5^{*} \Sigma \mathrm{MUFA}\right)+\right.$ $(0.5 * n-6)+(3 * n-3)+(n-3 / n-6)]$.

The hypocholesterolemic/Hypercholesterolemic ratio $(\mathrm{h} / \mathrm{H})$ was calculated according to Fernández et al. (2007): $\mathrm{h} / \mathrm{H}=[($ sum of $\mathrm{C} 18: 1 \mathrm{c}-n 9, \mathrm{C} 18: 1 n 7$, C18:2 n6, C18:3 n6, C18:3 n3, C20:3 n6, C20:4 n6, $\mathrm{C} 20: 5 n 3, \mathrm{C} 22: 4 n 6, \mathrm{C} 22: 5 n 3$ and $\mathrm{C} 22: 6 n 3) /($ sum of $\mathrm{C} 14: 0$ and $\mathrm{C} 16: 0)]$.

\subsection{Statistical analysis}

An analysis of variance (ANOVA), using the General Linear Model (GLM) procedure of the SPSS package (SPSS 19.0, Chicago, IL, USA) was performed for all variables considered in the study. When we studied the effect of genotype and location of the fat in the carcass on fatty acid composition, fixed the effects of anatomical location and genotype were included in the model. The model used was: $Y_{i j}=\mu+S_{i}+A_{j}+\varepsilon_{i j}$; where: $\mathrm{Y}_{\mathrm{ij}}$ is the observation of dependent variables, $\mu$ is the overall mean, $S_{i}$ is the effect of genotype, $A_{j}$ is the effect of location in the carcass, and $\varepsilon_{i j}$ is the residual random error associated with the observation. Correlations between variables $(\mathrm{P}<0.05)$ were determined using the Pearson's linear correlation coefficient.

\section{RESULTS}

\subsection{Effect of location}

Pork fat is mainly located in the subcutaneous area, perirenal area, between muscles (intermuscular) or between muscle fibers (intramuscular). The fatty acid composition of the total and neutral lipid fractions (from the three locations) are shown in Tables 3 and 4, respectively. The most abundant fatty acids were monounsaturated fatty acids (MUFA) (mainly C18:1 c- $n 9$, about $40-45 \%$ of total fatty acids in total lipids and $45-51 \%$ in neutral lipids), followed by saturated fatty acids (SFA) (approximately $38-43 \%$ in total lipids and 35-38\% in neutral lipids) and finally polyunsaturated fatty acids (PUFA) (approximately $7-14 \%$ in both types of lipids).

The total and neutral lipids of the intramuscular fat (IMF) showed significantly $(\mathrm{P}<0.05)$ higher values of MUFA and lower values of PUFA than the subcutaneous fat (SF), while SFA showed no significant differences $(\mathrm{P}>0.05)$ among the three locations. The greater MUFA content in IMF could be related to the higher contents of C18:1c-n9 $(\mathrm{r}=0.965$, $\mathrm{P}<0.01)$ and $\mathrm{C} 16: 1 n 7(\mathrm{r}=0.741, \mathrm{P}<0.01)$, while the lower PUFA content in this location could be linked to the smaller values of $\mathrm{C} 18: 2 n 6(\mathrm{r}=0.979, \mathrm{P}<0.01)$ and, to a lesser extent, to the contents of $\mathrm{C} 18: 3 \mathrm{n3}$ $(\mathrm{r}=0.593, \mathrm{P}<0.01)$ and $\mathrm{C} 20: 2 n 6(\mathrm{r}=0.789, \mathrm{P}<0.01)$.

The nutritional indices (IA, IT and $\mathrm{h} / \mathrm{H}$ ) presented significant differences $(\mathrm{P}<0.05)$ among locations, but did not show a clear trend (see Table 3). However, the polyunsaturated/saturated fatty acid $(\mathrm{P} / \mathrm{S})$ and $\sum \mathrm{n} 6 / \sum \mathrm{n} 3$ ratio presented significant differences $(\mathrm{P}<0.05)$ among locations, since the lowest 
values of the $\mathrm{P} / \mathrm{S}$ ratio were found in samples from IMF, while the lowest values of $\sum \mathrm{n} 6 / 2 \mathrm{n} 3$ ratio were obtained in samples from SF.

The fatty acid composition of polar lipids (from the three depots) is shown in Table 5. IMF presented a fatty acid profile totally different from that observed in SF. IMF polar lipids presented higher values of PUFA (between 37 and 44\%) than SF (between 12 and 17\%). However, SF showed higher percentages of MUFA (43-45\%) and SFA (39-44\%) than IMF (18-22\% MUFA and 36-38\% SFA) (see Table 5). These differences were due to IMF having higher contents of C18:2 $n 6$ and C20:4 $n 6$ (between $10-19 \%$ higher than SF), and a lower percentages of C16:0, C18:0 and C18:1c- $n 9$ than SF. On the other hand, the content of $\mathrm{C} 18: 3 \mathrm{n3}$ was greater in the subcutaneous locations than in IMF.

\subsection{Effect of genotype}

Table 2 shows the live weight, carcass weight, IMF and backfat thickness of the three genotypes of the Celta pig breed. Live weight $(\mathrm{P}<0.05)$, carcass weight $(\mathrm{P}<0.05)$ and IMF contents $(\mathrm{P}<0.001)$ were significantly different among the three lines. However, no significant differences $(\mathrm{P}>0.05)$ were observed in back fat thickness (Table 2). Although the effect of genotype on back fat thickness was not significant, some fatty acid from SF, as those from IMF, were still significantly influenced by genotype, suggesting the possible existence of a common mechanism for the regulation of some individual fatty acids from different locations. Regarding IMF, genotype also showed significant differences, since the highest values were obtained for Barcina $(5.21 \%)$, followed by the Carballiña $(3.59 \%)$ and Santiaguesa line $(1.99 \%)$.

The total lipids from IMF (Table 3) showed higher percentages of PUFA and MUFA and lower pecentages of SFA in the Santiaguesa line than in the Barcina and Carballiña genotypes. These values are due to the fact that the Santiaguesa line had higher contents $(\mathrm{P}<0.05)$ of $\mathrm{C} 16: 1 n 7, \mathrm{C} 18: 1 \mathrm{c}-n 9$ and $\mathrm{C} 20: 4$ $n 6$ than the other two lines, while the lowest values $(\mathrm{P}<0.05)$ of $\mathrm{C} 14: 0, \mathrm{C} 16: 0$ and $\mathrm{C} 20: 0$ were obtained for the Santiaguesa line. On the other hand, SF showed greater differences due to genotype in the dorsal fat location than in the ventral fat. In the dorsal fat, Carballiña and Santiaguesa genotypes had the highest values of PUFA, while the lowest values of SFA were obtained for the Santiaguesa line. In the ventral fat, the SFA content showed significant differences $(\mathrm{P}<0.05)$, and was also lower in the Santiaguesa line. The effects of genotype were different in the 3 locations, as indicated by significant genotype $\times$ location interactions for the percentages of C14:0, C16:0, C16:1 n7, C17:0, C17:1, C20:0 and C20:4 n6.

The nutritional indices also showed differences $(\mathrm{P}<0.05)$ by genotype. The Santiaguesa line showed higher values of $h / \mathrm{H}$ ratio and lower values of $\mathrm{AI}$ and TI (in IMF and ventral fat) indices than the other two lines.

The neutral lipids (Table 4) showed a similar trend to the total lipids. The santiaguesa line presented higher $(\mathrm{P}<0.05)$ values of PUFA than the other two genotypes. These differences were mainly due to the fact that the Santiaguesa line pigs had the highest content of C18:2 n6. In fact, the Pearson correlation test indicated that PUFA content was positively correlated with C18:2 n6 $(\mathrm{r}=0.968, \mathrm{P}<0.001)$. On the contrary, neutral lipids in the Santiaguesa genotype presented the lowest values of MUFA in the IMF and dorsal fat, while the SFA content did not show significant differences $(\mathrm{P}>0.05)$ among the three lines. The highest content of MUFA in the Barcina and Carballina lines was due to the higher values of $\mathrm{C} 18: 1 \mathrm{c}-\mathrm{n}$ 9 $(r=0.998$ and $r=0.997 ; \mathrm{P}<0.001$, for the Barcina and Carballina lines) which was higher in these genotypes compared to the Santiaguesa line. There were significant interactions between the effects of genotype and location for the percentages of $\mathrm{C} 20: 2$ $n 6$ and $\mathrm{C} 20: 4 n 6$.

TABLE 2. Number of pigs, live weight and carcass traits (mean \pm standard deviation values)

\begin{tabular}{lcccc}
\hline & \multicolumn{3}{c}{ Genotype } & \multirow{2}{*}{ Significance } \\
\cline { 2 - 4 } Trait & Barcina & Carballina & Santiaguesa & \\
\hline No of pigs & 15 & 15 & 15 & $*$ \\
Live Weight $(\mathrm{kg})$ & $171 \pm 15.5^{\mathrm{b}}$ & $184 \pm 17.9^{\mathrm{a}}$ & $178 \pm 25.5^{\mathrm{ab}}$ & $*$ \\
Carcass Weight $(\mathrm{kg})$ & $136 \pm 12.4^{\mathrm{b}}$ & $146 \pm 14.1^{\mathrm{a}}$ & $140 \pm 22.5^{\mathrm{ab}}$ & $* * *$ \\
Loin IMF $\left(\mathrm{g} \cdot 100 \mathrm{~g}^{-1}\right)$ & $5.21 \pm 1.72^{\mathrm{a}}$ & $3.59 \pm 1.11^{\mathrm{b}}$ & $1.99 \pm 0.72^{\mathrm{c}}$ & $\mathrm{ns}$ \\
Backfat thickness $(\mathrm{cm})$ & $5.89 \pm 0.90$ & $5.75 \pm 1.02$ & $6.37 \pm 1.56$ & \\
\hline
\end{tabular}

${ }^{\mathrm{a}-\mathrm{c}}$ Means within the same row not followed by the same letter differ significantly (influence by genotype)
$(\mathrm{P}<0.05)$; Significance: significantly different values as influenced by genotype $*(\mathrm{P}<0.05) ; * *(\mathrm{P}<0.01)$; $(\mathrm{P}<0.05)$; Significance: significantly different
$* * *(\mathrm{P}<0.001)$; ns: no significant difference. 
Effect of genotype on fatty acid composition of intramuscular and subcutaneous fat of Celta pig breed 5

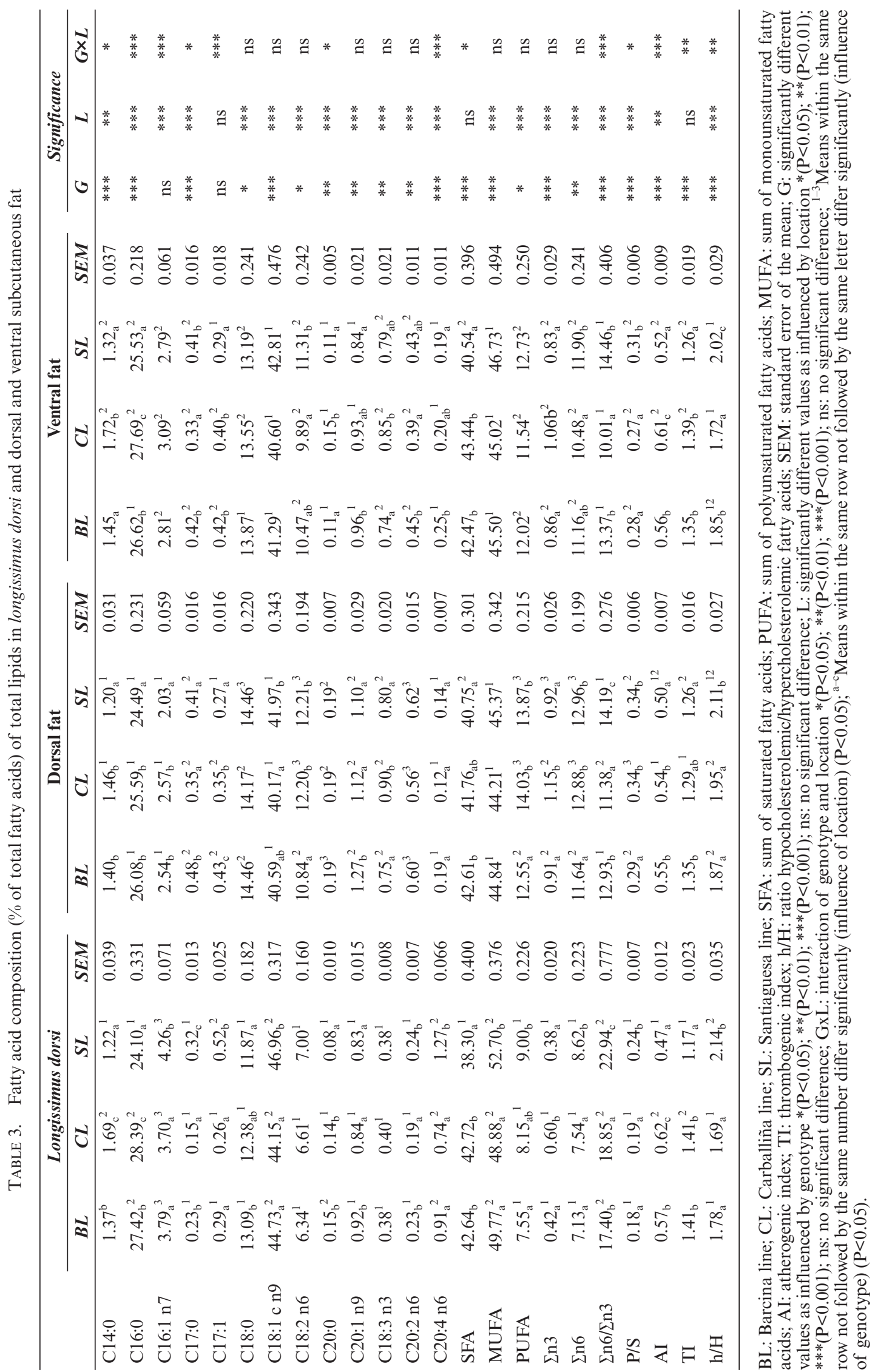

Grasas Aceites 65 (3), July-September 2014, e037. ISSN-L: 0017-3495 doi: http://dx.doi.org/10.3989/gya. 0234141 


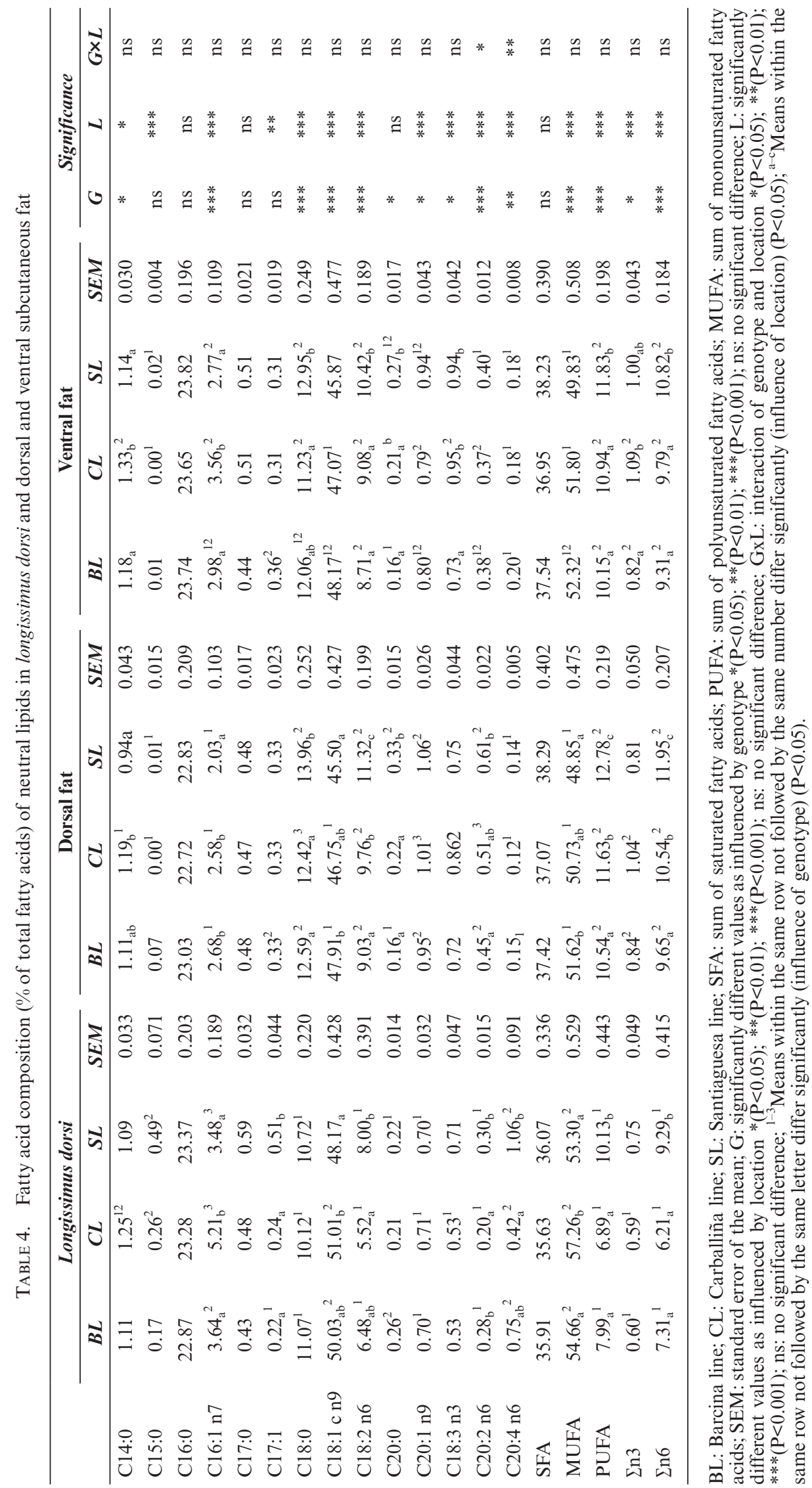




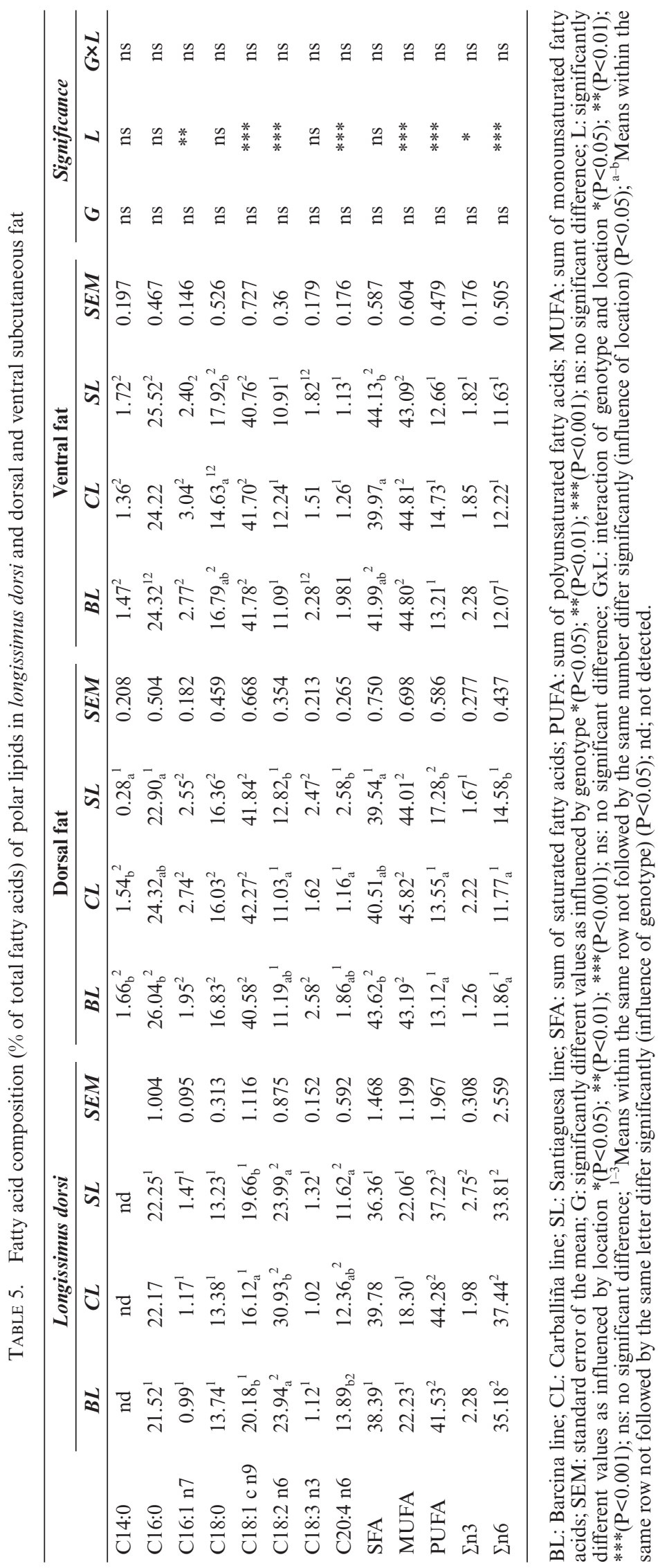


In the polar lipid fraction, there was a different behavior between intramuscular and subcutaneous fat. The IMF from the Santiaguesa line showed the lowest values ( $\mathrm{P}>0.05)$ of PUFA $(37.2 \%)$. Regarding ventral fat, there were observed significant $(\mathrm{P}<0.05)$ differences among the three genotypes in SFA contents since the highest values were obtained for the Santiaguesa line and this fact could be related to the greater amount of $\mathrm{C} 18: 0(\mathrm{r}=0.498 ; \mathrm{P}<0.01)$. On the other hand, in the dorsal fat location, the C18:0 content did not show significant $(\mathrm{P}>0.05)$ differences among genotypes, although the percentage of C16:0 and SFA contents presented significant $(\mathrm{P}<0.05)$ differences, since the lowest values were observed in the Santiaguesa line. In this location, the Santiaguesa genotype showed the highest values of PUFA, which also ocurred in the neutral and total lipids, mainly due to the higher values of $\mathrm{C} 18: 2 n 6$ and C20:4n6. In this case, there were no significant interactions between the effects of genotype and location.

\section{DISCUSSION}

\subsection{Effect of location}

The fatty acid compositions found in this study are consistent with those previously reported for the Celta pig breed (Franco et al., 2006; Lorenzo et al., 2012) and other rustic pig breeds such as Iberian (Daza et al., 2008), Chato Murciano (Galián et al., 2008; Peinado et al., 2009) and Cinta Senese (Franci et al., 2005; Pugliese et al., 2005).

On the other hand, the higher content of triglycerides than phospholipids in the IMF and SF locations (Estévez et al., 2003) causes the fatty acid profile of the neutral lipid fraction to be very similar to that found in the total lipid fraction.

The higher content of MUFA and lower PUFA in IMF than in SF were previously described in the literature (Raj et al., 2010; Bosch et al., 2012; Lorenzo et al., 2012).

Sellier (1998) and Estévez et al. (2003) described how the amount of fat influences the fatty acid composition of different fat deposits. These authors found that carcass leanness is inversely related to the proportion of SFA and MUFA in SF and IMF, whereas it is positively related to the content of most PUFA. Thus, an increase in PUFA content has been reported as fat deposition decreased (Raj et al., 2010; Bosch et al., 2012). In our study, a negative correlation was observed between IMF and PUFA content $(\mathrm{r}=-0.541 ; \mathrm{P}<0.01)$, as well as a positive correlation between IMF content and SFA $(\mathrm{r}=0.594 ; \mathrm{P}<0.01)$ in the intramuscular location and a negative correlation between backfat thickness and PUFA content $(\mathrm{r}=-0.351 ; \mathrm{P}=0.021)$ in the dorsal fat.

The differences found in the fatty acid composition in the different adipose tissues could be due to specific development and metabolism (Monziols et al., 2007). It is well known that muscles with an oxidative metabolism have a higher proportion of polar lipids, which are rich in PUFA and, therefore, have higher contents of PUFA than muscles with a glycolytic metabolism (Muriel et al., 2004). On the other hand, Monziols et al. (2007) noticed that the different fatty acid composition of adipose tissue could be due to an adipose tissue adaptation to the temperature in order to maintain the physical fluidity of lipids in the different deposits. C18:1c- $n 9$, the most abundant fatty acid in neutral and total lipids, is synthesized by $\Delta 9$-desaturase. Monziols et al. (2007) and Cánovas et al. (2009) explained that the activity of stearoyl Co-A desaturase and acetyl Co-A carboxylase varies depending on the location, which would explain the differences found in the present study for the content of MUFA.

Regarding nutritional indices, our P/S ratio was lower than the limit set by international institutions (Department of Health, 1994) and those reported by other authors (Cava et al., 2003; Raj et al., 2010). On the other hand, the $\sum \mathrm{n} 6 / \sum \mathrm{n} 3$ ratio was similar to that described by several authors for Iberian pigs (Estévez et al., 2003; Muriel et al., 2004; Juárez et al., 2009). Finally, the AI and TI indices were slightly higher than those reported by Franci et al., (2005) who found values ranging from 0.46 to 0.47 and from 1.09 to 1.16 for AI and TI indices, respectively.

The fatty acid compositions of the polar lipids found in this study are in agreement with those described for different lines of Iberian pigs (Estévez et al., 2003; Cava et al., 2004). The higher PUFA content of IMF would be related to the muscle, being rich in cell membranes with a higher proportion of phospholipids, which are rich in PUFA (Alasnier et al., 1996), while SF has a higher proportion of triglycerides. This may explain the differences in the contents of PUFA, SFA and MUFA from the polar lipid fraction among the three locations.

\subsection{Effect of genotype}

The effect of genotype on live weight have been previously described by Franco et al. (2011) who noticed a higher growth rate in the Carballiña than in the Santiaguesa line.

Regarding IMF content it is well known that the occurrence of intramuscular fat deposition has a strong genetic component (Gispert et al., 1997; Suzuki et al., 2009). In this case, the three genotypes of Celta pig showed a markedly different adipogenic capacity, since the Barcina line had more IMF compared to the other ones. This implies that the deposition of IMF and SF (total lipids) may be regulated by different mechanisms among the three lines. The activity of enzymes responsible for fatty acid metabolism and fat deposition depends on the genetic component. Ntawubizi et al. (2009) reported that the desaturase and elongase activity in muscles was 
significantly $(\mathrm{P}<0.05)$ related to the IMF content. Moreover, differences in fat infiltration have been reported to be mainly due to genetic influence (Poto et al., 2007; Juárez et al., 2009). Each 1\% genetic increase in lean content may reduce IMF by around $0.07 \%$ (Webb, 1998).

It is well known that traditional breeds are fattier than industrial ones. They have more adipose tissues thickness and more intramuscular fat (Tejeda et al., 2002; Gandemer, 2009). The differences in IMF are mainly due to higher triglyceride accumulation while the polar lipid fraction is similar between traditional and industrial genotypes of pigs. According to Gandemer (2009) this fact is due to the fact that traditional pigs have a low capacity to deposit muscles in carcass and deposit a large amount of the feed energy as fat in both adipose and intramuscular depots.

The differences in nutritional indices among the three lines could be due to different amounts of SFA, which were lower in the Santiaguesa genotype. In fact, the Pearson correlation test indicated that SFA were significantly $(\mathrm{P}<0.01)$ related to the IA $(\mathrm{r}=0.803)$, IT $(\mathrm{r}=0.961)$ and $\mathrm{h} / \mathrm{H}$ ratio $(\mathrm{r}=-0.833)$.

There is controversy about the effect that genotype has on the fatty acid composition. Gandemer and Viau (1992) and Tejeda et al. (2002) have reported that genotype slightly affected the triglycerides and fatty acid composition, while Ventanas et al. (2006) have reported significant differences in fatty acids between purebred and crossbreed, even for animals fed on the same diet. In agreement with this, Vieira-Alcaide et al. (2008) concluded that the triglyceride composition of the subcutaneous fat of Iberian pigs is affected by genotype. These authors suggested that the different activities of stearoyl CoA desaturase between genotypes are the main cause of the differences in the fatty acid and triglyceride contents.

It is well known that de novo synthesis causes an increase in the content of SFA and/or MUFA, while it decreases the values of the PUFA (Warnants et al., 1999; Kloareg et al., 2005; Gandemer, 2009). Fatty acids from de novo synthesis are deposited mainly in the neutral lipid fraction, thus the dilution effect is more intense in this fraction than in polar lipids (Muriel et al., 2004). In our case, we observed a strong dilution of the PUFA content in total and neutral lipid fractions as the result of increased fat content from the IMF and SF locations, however this effect was not observed on polar lipids. These results are in agreement with those reported by Gandemer (2009), who found that genotype slightly affected the fatty acid composition from polar lipids.

Some experiments focused on the relationship between fatty acid composition and genotypes demonstrate that this parameter has a low effect when animals are compared at the same degree of fatness (Gandemer, 2009). Therefore, differences in fatty acid composition are mainly explained by differences in the fatness of the carcasses and the muscles. However, according to Gandemer and Viau (1992) any variation in the relative proportions of endogenous and dietary lipids stored in the muscle or in the elongation and desaturation abilities of fatty acids according to genotype would lead to differences in the fatty acid composition.

Thus, our results suggest that differences in lipid content may be due, as mentioned above, to the different enzyme activity and the differences in fatness, and differences in fatty acid profile could be a consequence of differences in de novo synthesis and turnover between the three lines of Celta pig breed, in agreement with values reported by Franci et al. (2005).

\section{CONCLUSIONS}

There were very evident differences in IMF content and fatty acid profile among the three Celta pig lines. The differences may be due to a genetic component that regulates the metabolism of fatty acids and the amount of fat deposited in the animal tissues. The effect of genotype on fatness was mainly due to differences in the proportion of triglycerides. In fact, the fatty acid composition from polar lipids was hardly affected by genotype. Further studies are needed to clarify the mechanisms that differentiate fat deposition and fatty acid metabolism among the Celta pig lines.

\section{ACKNOWLEDGEMENTS}

The authors are grateful to the Xunta de Galicia (The Regional Government) (Project 09MRU013E) for their financial support.

\section{REFERENCES}

Alasnier C, Rémignon H, Gandemer G. 1996. Lipid characteristics associated with oxidative and glycolitic fibres in rabbit muscles. Meat Sci. 43, 213-224. http://dx.doi.org/10.1016/ S0309-1740(96)00015-0.

Bermúdez R, Franco I, Franco D, Carballo J, Lorenzo JM. 2012. Influence of inclusion of chestnut in the finishing diet on fatty acid profile of dry-cured ham from Celta pig breed. Meat Sci. 92, 394-399. http://dx.doi.org/10.1016/j. meatsci.2012.05.001

Bosch L, Tor M, Reixach J, Estany J. 2012. Age-related changes in intramuscular and subcutaneous fat content and fatty acid composition in growing pigs using longitudinal data. Meat Sci. 91, 358-363. http://dx.doi.org/10.1016/j. meatsci.2012.02.019.

Cánovas A, Estany J, Tor M, Pena RN, Doran O. 2009. AcetylCoA carboxylase and stearoyl-CoA desaturase protein expression in at constant intramuscular fat content subcutaneous adipose tissue is reduced in pigs selected for decreased backfat thickness. J. Anim. Sci. 87, 3905-3914. http://dx.doi.org/10.2527/jas.2009-2091

Carreau JP, Dubacq JP. 1978. Adaptation of a macro-scale method to themicro-scale for fatty acid methyl transesterification of biological lipid extracts. J. Chromatogr. A 151, 384-390. http://dx.doi.org/10.1016/S0021-9673(00)88356-9. 
Carril JA, Ribero CJ, Fernández M, Lorenzo JM. 2012. La raza. In: Manual del Cerdo Celta (CETECA eds.). Ourense (Spain), pp: 17-41.

Cava R, Estévez M, Ruiz J, Morcuende D. 2003. Physicochemical characteristics of three muscles from free-range reared Iberian pigs slaughtered at $90 \mathrm{~kg}$ live weight. Meat Sci. 63, 533-541. http://dx.doi.org/10.1016/S0309-1740(02) 00180-8.

Cava R, Ferrer JM, Estévez M, Morcuende D, Toldrá F. 2004. Composition and proteolytic and lipolytic enzyme activities in muscle Longissimus dorsi from Iberian pigs and industrial genotype pigs. Food Chem. 88, 25-33. http:// dx.doi.org/10.1016/j.foodchem.2003.07.037.

Daza A, Rey IA, López-Carrasco C, López-Bote CJ. 2008. Influence of acorn size on growth performance, carcass quality and fatty acid composition of subcutaneous and intramuscular fat from Iberian pigs fattened in confinement. Spanish. J Agric Res 6, 230-235. http://dx.doi. org/10.5424/sjar/2008062-314

De Pedro E, Casillas M, Miranda CM. 1997. Microwave oven application in the extraction of fat from the subcutaneous tissue of I berian pig ham. Meat Sci. 45, 45-51. http:// dx.doi.org/10.1016/S0309-1740(96)00097-6.

Department of Health. 1994. Nutritional aspects of cardiovascular disease. Her Majesty's Stationer Office, London: Report on Health and Social Subjects, No. 46.

Estévez M, Morcuende D, Cava R. 2003. Physico-chemical characteristics of M. Longissimus dorsi from three lines of freerange reared Iberian pigs slaughtered at $90 \mathrm{~kg}$ live-weight and commercial pigs: a comparative study. Meat Sci. 64, 499506. http://dx.doi.org/10.1016/S0309-1740(02)00228-0

Fernández M, Ordoñez JA, Cambero I, Santos C, Pin C, de la Hoz L. 2007. Fatty acid composition of selected varieties of Spanish dry ham related to their nutritional implications. Food Chem. 101, 107-112. http://dx.doi.org/10.1016/j. foodchem.2006.01.006.

Folch J, Lees M, Sloane-Stanley GH. 1957. A simple method for the isolation and purification of total lipids from animal tissues. J Biol Chem. 226, 497-509.

Franci O, Bozzi R, Pugliese C, Acciaioli A, Campodoni G, Gandini G. 2005. Performance of CintaSenese pigs and their crosses with Large White. 1. Muscle and subcutaneous fat characteristics. Meat Sci. 69, 545-550. http:// dx.doi.org/10.1016/j.meatsci.2004.10.005.

Franco I, Escamilla MC, García J, García-Fontán MC, Carballo J. 2006. Fatty acid profile of the fat from Celta pig breed fattened using a traditional feed. Effect of the location in the carcass. J Food Compos. Anal. 19, 792-799.

Franco D, Lorenzo JM. 2013. Effect of gender (barrows vs. females) on carcass traits and meat quality of Celta pig reared outdoors. J. Sci. Food Agric. 93, 727-734. http:// dx.doi.org/10.1002/jsfa.5966.

Franco D, García A, Vázquez JA, Fernández M, Carril JA, Lorenzo JM. 2011. Curvas de crecimiento de dos ecotipos (Santiaguesa vs. Carballina) de "cerdo Celta". In: XIV Jornadas sobre Producción Animal AIDA, Spain, pp. 37-39.

Franco D, Vázquez JA, Lorenzo JM. 2014. Growth performance, carcass and meat quality of the Celta pig crossbred with Duroc and Landrance genotypes. Meat Sci. 96, 195-202.

Galián M, Poto A, Santaella M, Peinado B. 2008. Effects of the rearing system on the quality traits of the carcass, meat and fat of the Chato Murciano pig. Anim Sci. J. 79, 487497. http://dx.doi.org/10.1111/j.1740-0929.2008.00554.x.

Gandemer G, Viau M. 1992. Lipid composition of adipose tissue and muscle in pigs with an increasing proportion of Meishan genes. Meat Sci. 32, 105-121. http://dx.doi. org/10.1016/0309-1740(92)90020-5.

Gandemer G. 2009. Dry cured ham quality as related to lipid quality of raw material and lipid changes during processing: a review. Grasas Aceites 60, 297-307. http://dx.doi. org/10.3989/gya.130908.

Gispert M, Valero A, Oliver MA, Diestre A. 1997. Problemas asociados a la falta de grasa en las canales porcinas. Eurocarne 61, 27-32.
Juárez M, Clemente I, Polvillo O, Molina A. 2009. Meat quality of tenderloin Iberian pigs as affected by breed strain and crossbreeding. Meat Sci. 81, 573-579. http://dx.doi. org/10.1016/j.meatsci.2008.10.016

Kaluzny MA, Duncan LA, Merritt MV, Epps DE. 1985. Rapid separation of lipids classes in high yield and purity using bonded phase columns. J. Lipid Res. 26, 135-140.

Kloareg M, Le Bellego L, Mourot J, Noblet J, Van Milgen J. 2005. Deposition of dietary fatty acids and of de novo synthetized fatty acids in growing pigs: effects of high ambient temperature and feeding restriction. Br. J. Nutr. 93, 803811. http://dx.doi.org/10.1079/BJN20051420.

Lorenzo JM, Montes R, Purriños L, Cobas N, Franco D. 2012. Fatty acid composition of Celta pig breed as influenced by sex and location of fat in the carcass. J. Sci. Food Agric. 92, 1311-1317. http://dx.doi.org/10.1002/jsfa.4702.

Martínez S, Cachaldora A, Fonseca S, Franco I, Carballo J. 2007. La grasa del cerdo de raza celta: Perfil de ácidos grasos de los lípidos neutros y polares en distintas localizaciones de la canal. Eurocarne 154, 65-79.

Monziols M, Bonneau M, Davenel A, Kouba M. 2007. Comparison of the lipid content and fatty acid composition of intramuscular and subcutaneous adipose tissues in pig carcasses. Meat Sci. 76, 54-60. http://dx.doi. org/10.1016/j.meatsci.2006.10.013.

Morales J, Pérez JF, Baucells MD, Mourot J, Casa J. 2002. Comparative digestibility and lipogenic activity in Landrace and Iberian finishing pigs fed ad libitum corn- and cornsorghumacorn-based diets. Livest Prod. Sci. 77, 195-205. http://dx.doi.org/10.1016/S0301-6226(02)00063-5.

Muriel E, Ruiz J, Ventanas J, Petrón MJ. 2004. Antequera T, Meat quality characteristics in different lines of Iberian pigs. Meat Sci. 67, 299-307. http://dx.doi.org/10.1016/j. meatsci.2003.11.002.

Ntawubizi M, Raes K, Buys N, De Smet S. 2009. Effect of sire and sex on the intramuscular fatty acid profile and indices for enzyme activities in pigs. Livest. Sci. 122, 264-270. http://dx.doi.org/10.1016/j.livsci.2008.09.008

Peinado B, Almela L, Duchi N, Poto A. 2009. Parámetros de calidad en la canal y en la carne del cerdo Chato Murciano. Eurocarne 173, 64-80.

Poto A, Galian M, Peinado B. 2007. ChatoMurciano pig and its crosses with Iberian and large white pigs, reared outdoors. Comparative study of the carcass and meat characteristics. Livest Prod Sci. 111, 96-103. http://dx.doi.org/10.1016/j. livsci.2006.12.005.

Pugliese C, Bozzi R, Campodoni G, Acciaioli A, Franci O, Gandini G. 2005. Performance of Cinta Senese pigs reared outdoors and indoors. 1. Meat and subcutaneous fat characteristics. Meat Sci. 69, 459-464. http://dx.doi. org/10.1016/j.meatsci.2004.09.001.

Raj ST, Skiba G, Weremko D, Fandrejewski H, Migdał W, Borowiec F, Poławska E. 2010. The relationship between the chemical composition of the carcass and the fatty acid composition of intramuscular fat and backfat of several pig breeds slaughtered at different weights. Meat Sci. 86, 324-330. http://dx.doi.org/10.1016/j.meatsci.2010. 04.037 .

Sellier P. 1998. Genetics of meat and carcass traits. In: The Genetics of the Pigs (Rothschild MF, Ruvinsky A, eds.) France, pp: 463-510

Suzuki K, Inomata K, Katoh K, Kadowaki H, Shibata T. 2009. Genetic correlations among carcass cross-sectional fat area ratios, production traits, intramuscular fat, and serum leptin concentration in Duroc pigs. J. Anim. Sci. 87, 2209-2215. http://dx.doi.org/10.2527/jas.2008-0866

Tejeda JF, Gandemer G, Antequera T, Viau M, García C. 2002. Lipid traits of muscles as related to genotype and fattening diet in Iberian pigs: total intramuscular lipids and triacylglycerols. Meat Sci. 60, 357-363. http://dx.doi.org/10.1016/ S0309-1740(01)00143-7.

Ulbricht TLV, Southgate DAT. 1991. Coronary heart disease: Seven dietary factors. Lancet 338, 985-992. http://dx.doi. org/10.1016/0140-6736(91)91846-M

Ventanas S, Ventanas J, Jurado A, Estevez M. 2006. Quality traits in muscle biceps femoris and back-fat from purebred Iberian 
Effect of genotype on fatty acid composition of intramuscular and subcutaneous fat of Celta pig breed 11

and reciprocal I berian $\times$ Duroc crossbred pigs. Meat Sci. 73, 651-659. http://dx.doi.org/10.1016/j.meatsci.2006.03.009.

Vieira-Alcaide I, Vicario IM, Escudero-Gilete ML, Constante EG, León-Camacho M. 2008. A multivariate study of the triacylglycerols composition of the subcutaneous adipose tissue of Iberian pig in relation to the fattening diet and genotype. Grasas Aceites 59, 327-336.
Warnants N, Van Oeckel MJ, Boucqué CV. 1999. Incorporation of dietary polyunsaturated fatty acids into pork fatty tissues. J. Anim. Sci. 77, 2478-2490.

Webb AJ. 1998. Objectives and strategies in pig improvement: An applied perspective. J. Dairy Sci. 81, 36-46. http:// dx.doi.org/10.3168/jds.S0022-0302(98)70152-3. 